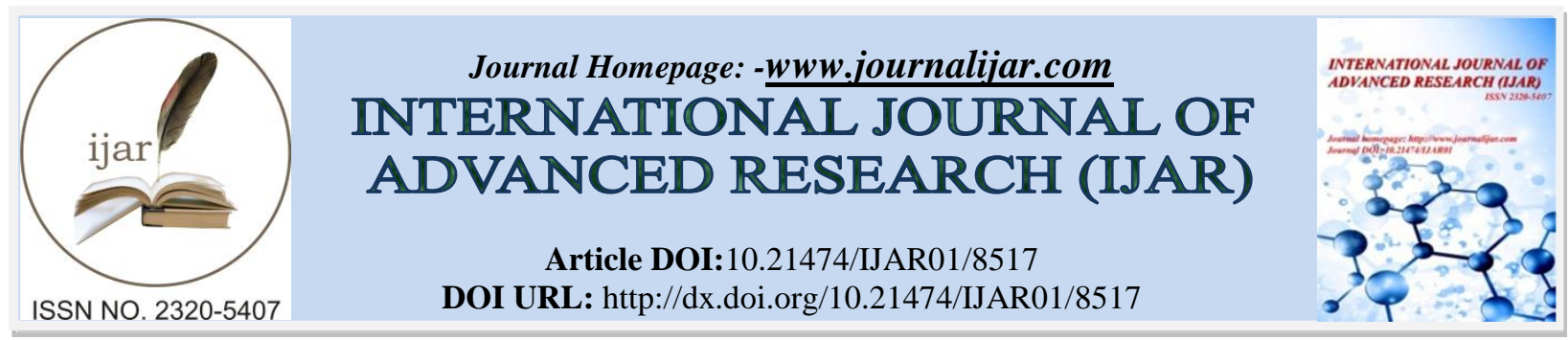

RESEARCH ARTICLE

\title{
THE LONG-RUN RELATIONSHIP BETWEEN OUTPUT, MONEY, AND PRICES: EMPIRICAL EVIDENCE FROM SYRIA.
}

\section{Burhan Ali ${ }^{1}$ and Zeina Al-Ahmad ${ }^{2}$.}

1. MSc. Student, Faculty of Economics, Tishreen University.

2. Assistant Professor, Faculty of Economics, Tishreen University.

\section{Manuscript Info}

Manuscript History

Received: 06 December 2018

Final Accepted: 08 January 2019

Published: February 2019

Key words:-

Co-integration, Nominal GDP, Money

Supply, Inflation, Syria.

\section{Abstract}

The aim of this study is to examine the long-run relationship between nominal GDP, money supply and inflation rate in Syria over the period 1980-2012. Using annual data, the Johansen Co-integration analysis was applied in order to investigate the long-run relationship between the variables in question. The results revealed that there is a long-run equilibrium relationship between the three variables. More specifically, the GDP is positively related to money supply but negatively related to inflation over the long run. Similarly, inflation is positively related to money supply but negatively related to GDP. However, money supply is positively related to both GDP and inflation over the long run.

Copy Right, IJAR, 2019,. All rights reserved.

\section{Introduction:-}

Output, money and prices are considered very important indicators of macroeconomic performance, therefore it is crucial for policy makers to understand and analyze the dynamic relationship between these variables in order to achieve economic stability and growth.

Different economic schools have different views on the relationship between these variables. The Monetarists considered money supply as the key variable in stabilizing the economy. The Monetarists postulated, based on the Quantity Theory of Money (QTM), that the quantity of money is the main determinant of the price level. The QTM is illustrated by using the Fisher equation: MV=PY where M stands for money supply; $\mathrm{V}$ for velocity of money; $\mathrm{P}$ for the average price level; and Y for real aggregate output. The QTM assumes that V and Y are constant in the long-run, thus the equation becomes $\% \Delta \mathrm{M}=\% \Delta \mathrm{P}$. This equation means that any change in the money supply will cause the same change in the price level. Therefore, the monetarists emphasized that in the long-run, changes in the money supply only cause changes in the price level. However, these changes would not affect the real output. On the contrary, the Keynesians suggest that money can affect the output at least in the short-run. They argue that inflation affects economic growth positively through interest rate. When the quantity of money increases, the interest rate falls, causing an increase in the amount of investments and aggregate demand, thereby raising the output (Bello and Saulawa, 2013; Bozkurt, 2014).

Understanding the relationship between output, money and inflation is of high importance for any economy as this would help in drawing economic policies that lead to sustainable economic growth and price stabilization. Therefore, the focus of this paper is to examine the relationship between output, money and inflation in Syria for the 
period 1980-2012. This paper contributes to the literature on examining the relationship between the three variables in a period that covers the financial liberalization that took place in Syria.

The rest of the paper is organized as follows: Section 2 reviews the literature. Section 3 explains the data collection and methodology. Section 4 presents the empirical results and discussion, and section 5 concludes the paper.

\section{Literature Review:-}

The relationship between output, money and inflation has been investigated by different empirical studies in both developed and developing countries. While some empirical studies concluded a long-run relationship between these variables other studies did not find such a relationship. In addition, it appears that the dynamics of the relationship between these variables may vary regarding the economy under study.

Al-Mosabbeh (2006) studied the determinants of inflation in Syria for the period (1972-2005) by using cointegration and causality tests. The study reported that there is one co-integration equation among the investigated variables, and the equation showed that in the long-run both GDP and money supply have a positive effect on inflation.

Jiranyakul (2009) investigated the relationship among money aggregates (M1, M2 and M3), velocity of money, prices (CPI and GDP deflator) and nominal GDP in Thailand using quarterly data from 1993Q1 to 2006Q4. The researcher used Auto Regressive Distributed Lag (ARDL) in order to test the co-integration relationship between the variables under study. The results indicated the existence of a long-run relationship between the variables where GDP has a positive impact on real money demand; money supply (M1) and velocity of money have positive impacts on GDP, and money supply (M1) has a positive impact on price level.

Ahmed and Suliman (2011) examined the relationship between real GDP, money supply (M2) and price level (Consumer Price Index (CPI)) in Sudan using annual data over the period 1960 to 2005. Johansen co-integration was used to examine the existence of a long-run relationship between the three variables. The results showed that there is one long-run relationship between the variables, and the equation showed that money supply has a negative impact on real GDP, while CPI has a positive impact on real GDP in the long-run.

Al-Fawwaz and Al-Sawai'e (2012) analyzed the long-run relationship between GDP growth, money supply (M1) and prices for the Jordanian economy using annual data for the period 1976-2009. The authors utilized the Johansen procedure of co-integration to test for the existence of a long-run relationship between the variables. The results showed that there is no co-integration relationship between the variables in Jordan.

Shams (2012) examined the relationship between GDP, money supply (M1) and prices (CPI) in Bangladesh during the period 1972-2010. The Johansen co-integration test is used to examine whether the variables have a common trend in the long-run. The results showed that the variables are co-integrated and have a long-run relationship.

Bello and Saulawa (2013) examined the relationship between money supply, interest rate, GDP growth and inflation rate in Nigeria for the period 1980-2010. The Johansen test for co-integration was used, and the results revealed that there is no co-integration relationship between the variables in the long-run.

Bozkurt (2014) examined the relationship between money supply (M2), GDP, velocity of money and deflator in Turkey, using quarterly data for the period 1992Q2 to 2012Q2. The Johansen co-integration test was used to examine the existence of a long-run relationship between the variables under study. The results showed that there were two cointegrating vectors, and the equation showed that GDP has a negative impact on inflation whereas both money supply and velocity of money have positive impacts on inflation.

Naeem et al. (2014) analyzed the relationship between money supply and inflation in Syria for the period (19962010) by applying co-integration and causality tests. They found that there is no co-integration relationship between money supply and inflation in the long-run.

Denbel et al. (2016) examined the relationship between inflation (CPI), money supply (M2) and economic growth (real GDP) in Ethiopia for the period 1970-2011. The Johansen co-integration test was applied and the results 
indicated the presence of one co-integration equation between the variables. Results from the equation showed that in the long-run, money supply has a positive impact on inflation, while real GDP has a negative impact on inflation.

Hasanov et al. (2017) examined the relationship between broad money, GDP, prices and interest rate in Saudi Arabia for the period 1970-2016. Using Johansen co-integration test, the researchers found that there is a long-run relationship between broad money measures, income, prices and interest rate. The long-run equation showed that money supply is positively related to both GDP and prices.

Bala and Chin (2018) examined the impact of oil price, money supply, food production index, exchange rate, and GDP on CPI inflation in four countries (Algeria, Angola, Libya and Nigeria). Using panel data with annual frequency for the period 1995-2014, the authors applied panel co-integration test in order to determine the existence of the long-run relationship between the variables under study. Moreover, ARDL dynamic panels were used to estimate the short-run and long-run dynamic relationships. The results revealed the existence of long-run relationship between the variables where inflation is positively related to money supply, GDP and exchange rate.

Reviewing the previous literature indicates that some of the studies have found a long-run relationship between output, money and prices (Al-Mosabbeh, 2006; Jiranyakul, 2009; Ahmed and Suliman, 2011; Shams, 2012; Bozkurt, 2014; Denbel et al., 2016) while others could not find such a relationship between the three variables (AlFawwaz and Al-Sawai'e, 2012; Bello and Saulawa, 2013; Naeem et al., 2014). The results appear to differ according to the country of study and the period of study.

The inconclusive evidence regarding the relationship between the three variables and the sensitivity of the results to the period of study examined motivated us to examine the relationship in Syria using the most up to date data that includes a period of financial liberalization ${ }^{1}$.

\section{Data and Methodology:-}

Data:-

This study uses annual time series data of the output level, money and prices from 1980 to 2012 (33 observations). The level of output is measured, following Al-Fawwaz and Al-Sawai'e, (2012), by the nominal Gross Domestic Product (GDP). Money is measured, following Bello and Saulawa (2013) and Denbel et al. (2016), as the broad money supply (M2), which comprises the sum of currency outside banks, demand deposits other than those of the central government, and the time, savings, and foreign currency deposits of resident sectors other than the central government. Inflation is measured as the annual percentage change of Consumer Price Index (CPI). Both nominal GDP and M2 were measured using natural logarithm ${ }^{2}$.

The main source of data is the World Development Indicators (WDI) database of World Bank (WB) for the period until 2010. After this year, the researchers used the Arab Monetary Fund database and the Central Bank of Syria (CBS) database due to unavailability of data related to Syria in the WDI database after 2010. Worth noting that changing the source of data is not expected to affect the results as the three sources of data did not show significant differences during the periods covered by the three of them.

\section{Methodology:-}

In order to examine the relationship between nominal GDP, broad money supply and inflation rate in the long-run, three multiple regression models are specified:

$$
\begin{aligned}
& \text { LNGDP }_{t}=\alpha+\beta_{1} \text { LNMS }_{t}+\beta_{2} \text { INF }_{t}+\varepsilon_{t} \\
& \text { LNMS }_{t}=\alpha+\beta_{1} \text { LNGDP }_{t}+\beta_{2} \text { INF }_{t}+\varepsilon_{t} \\
& \text { INF }_{t}=\alpha+\beta 1 \text { LNGDP }_{t}+\beta 2 \text { LNMS }_{t}+\varepsilon t
\end{aligned}
$$

Where:

LNGDP $_{\mathrm{t}}$ : The natural logarithm of nominal GDP for period t; LNMS $_{\mathrm{t}}$ : The natural logarithm of broad money supply (M2) for period $t$; INF ${ }_{t}$ : The inflation rate for period $t$; $\varepsilon t$ : error term; $\alpha$ : Constant term; $\beta_{1}, \beta_{2}$ : estimated coefficients for the corresponding variables; $t$ : The year under examination.

\footnotetext{
${ }^{1}$ The time periodcould not be extended further due to limitations on data availability for Syria.

${ }^{2}$ The naturallogarithm of inflation rate variable is not takenbecauseitcontainsnegative values.
} 
The Augmented Dickey-Fuller (ADF) unit root test was performed in order to test whether the variables are stationary and in order to know the order of integration of the variables. The three possible forms of the ADF unit root test are given by the following equations (Asteriou and Hall, 2007):

$$
\begin{aligned}
& \Delta y_{t}=\gamma y_{t-1}+\sum_{i=1}^{p} \beta_{i} \Delta y_{t-i}+u_{t} \\
& \Delta y_{t}=\alpha_{0}+\gamma y_{t-1}+\sum_{i=1}^{p} \beta_{i} \Delta y_{t-i}+u_{t} \\
& \Delta y_{t}=\alpha_{0}+\gamma y_{t-1}+\alpha_{2} t+\sum_{i=1}^{p} \beta_{i} \Delta y_{t-i}+u_{t}
\end{aligned}
$$

Where $\Delta y_{t}$ is the first difference of series $y_{t} ; y_{t-1}$ is the lagged series; $\alpha_{0}$ is the constant term; $\mathrm{t}$ is the linear time trend; $\mathrm{p}$ is the lag length; $u_{t}$ is the error term. The lag length in the unit root tests was chosen based on Schwarz Information Criterion (SIC).

The difference between the three regressions lies on the presence of the constant $\alpha_{0}$ and the trend $t$. The first model is without intercept and trend. The second model is with an intercept only. The third model is with both the intercept and the trend. The null hypothesis of the ADF unit root test is Ho: $\gamma=0$ which states the presence of a unit root (i.e. the series is not stationary) whereas the alternative hypothesis H1: $\gamma<0$ states that the series is stationary (does not have a unit root).

The ADF unit root test enables us to test the order of integration of the variables. The variable $y_{t}$ is integrated of order $\mathrm{d}$ if it becomes stationary after $\mathrm{d}$ numbers of differences. If all variables are integrated of the same order ${ }^{3}$ then we can estimate the long-run (possible co-integration) relationship between them using the Johansen co-integration test (Johansen, S., and Juselius, K., 1990; Johansen, 1991).

If the variables under study turn out to be integrated of the same order, the appropriate lag length of the model would be chosen, and then the Johansen co-integration test would be applied in order to determine the existence of a long-run relationship between the examined variables. The Johansen procedure assumes the following Vector Auto Regressive (VAR) model (Brooks, 2014):

$$
\gamma_{t}=\beta_{1} \gamma_{t-1}+\beta_{2} \gamma_{t-2}+\cdots+\beta_{k} \gamma_{t-k}+u_{t}
$$

Where $\gamma$ is a vector of the three variables under study $\left(\gamma=\left\{N G D P_{t}, M S_{t}, I N F_{t}\right\}\right)$; $\mathrm{k}$ is the number of lags.

Testing for co-integration under the Johansen approach, is usually done by two test statistics which are formulated as follows (Brooks, 2014):

The trace test:

$$
\lambda_{\text {trace }}(r)=-T \sum_{i=r+1}^{g} \ln \left(1-\hat{\lambda}_{i}\right)
$$

The maximum eigenvalue test:

$$
\lambda_{\max }(r, r+1)=-T \ln \left(1-\hat{\lambda}_{r+1}\right)
$$

Where $r$ is the number of co-integrating vectors under the null hypothesis; $\hat{\lambda}$ is the estimated value for the ith ordered eigenvalue from the $\Pi$ matrix.

The null hypothesis of the trace test is that the number of co-integrating vectors is less than or equal to $r$ against an unspecified or general alternative that there are more than $\mathrm{r}$. The null hypothesis of the maximum eigenvalue test is that the number of co-integrating vectors is $r$ against an alternative of $r+1$.

\footnotetext{
${ }^{3}$ Economic variables are usually I(1) process (Asteriou and Hall, 2007).
} 


\section{Empirical Results:-}

Unit Root Test:-

The ADF unit-root test results for the levels and first differences of the variables are presented in table (1). The results indicate the failure to reject the null hypothesis for all the variables in question in level terms, as the absolute value of $t$-statistic is lower than the absolute value of the critical $t$ at the 5 percent level of significance. Thus, all variables are non-stationary at levels. After taking the first difference, the null hypothesis of unit root is rejected and all variables became stationary. Thus we can conclude that the three variables under study are integrated of order (1) or I (1) process.

Table 1:-Unit-root test

\begin{tabular}{|c|c|c|c|c|c|c|c|}
\hline Variables & \multicolumn{2}{|c|}{ ADF test results in the levels } & \multicolumn{2}{c|}{ ADF test results in first differences } & Result \\
\cline { 2 - 8 } & t-statistics & $\begin{array}{c}\text { critical } \\
\text { value at 5\% }\end{array}$ & $\begin{array}{c}\text { Model } \\
\text { Selection }\end{array}$ & t-statistics & $\begin{array}{c}\text { critical } \\
\text { value at 5\% }\end{array}$ & $\begin{array}{c}\text { Model } \\
\text { Selection }\end{array}$ & \\
\hline LNGDP & -1.091984 & -3.557759 & $\begin{array}{c}\text { Intercept } \\
\text { and Trend }\end{array}$ & -4.274945 & -3.562882 & $\begin{array}{l}\text { Intercept and } \\
\text { Trend }\end{array}$ & $\mathrm{I}(1)$ \\
\hline LNMS & -2.428877 & -3.557759 & $\begin{array}{c}\text { Intercept } \\
\text { and Trend }\end{array}$ & -3.956970 & -3.562882 & $\begin{array}{l}\text { Intercept and } \\
\text { Trend }\end{array}$ & $\mathrm{I}(1)$ \\
\hline INF & -1.613040 & -3.557759 & $\begin{array}{c}\text { Intercept } \\
\text { and Trend }\end{array}$ & -3.867029 & -3.562882 & $\begin{array}{l}\text { Intercept and } \\
\text { Trend }\end{array}$ & $\mathrm{I}(1)$ \\
\hline
\end{tabular}

Note: Lag length is chosen automatically based on Schwarz Information Criterion (SIC).

Source: Compiled by authors based on EViews V.9

\section{Lag Length Selection:-}

Having determined that all the variables under study are integrated of order I(1), then the condition to apply Johansen co-integration test is satisfied. However, before the estimation of the Johansen co-integration test, the optimal lag length should be chosen by estimating the VAR model including all three variables in levels and choosing the lag length in which the model has the lowest value of the lag length criteria (Asteriou and Hall, 2007).

Four lag length criteria are employed in order to determine the optimal lag length. These criteria are Final Prediction Error (FPE), Akaike Information Criterion (AIC), Schwarz Information Criterion (SIC) and the Hannan-Quinn Information Criterion (HQ). Based on the FPE, AIC, SIC, and HQ tests, the results presented in table (2) reveal that lag (1) is the optimal lag length for the variables under study.

Table 2:-Lag Order Selection Criteria

VAR Lag Order Selection Criteria

Endogenous variables: INF LNMS LNGDP

Exogenous variables: $\mathrm{C}$

Sample: 19802012

Included observations: 27

\begin{tabular}{l|l|l|l|l|}
\hline Lag & FPE & AIC & SIC & HQ \\
\hline 0 & 3.419787 & 9.743108 & 9.887090 & 9.785921 \\
\hline 1 & $0.004854^{*}$ & $3.179053^{*}$ & $3.754981^{*}$ & $3.350307^{*}$ \\
\hline 2 & 0.006458 & 3.434899 & 4.442772 & 3.734592 \\
\hline 3 & 0.010176 & 3.815043 & 5.254861 & 4.243176 \\
\hline 4 & 0.015021 & 4.054773 & 5.926537 & 4.611346 \\
\hline 5 & 0.020804 & 4.106674 & 6.410384 & 4.791688 \\
\hline 6 & 0.024112 & 3.763219 & 4.576673 \\
\hline *Indicates lag order selected by the criterion & \\
FPE: Final prediction error & AIC: Akaike information criterion \\
SIC: Schwarz information criterion \\
HQ: Hannan-Quinn information criterion
\end{tabular}

Source: Compiled by authors based on EViews V.9 


\section{Johansen Co-integration Test:-}

Johansen co-integration test was used in order to determine the existence of a long-run relationship between nominal GDP, money supply and inflation rate. The results of trace and maximum eigenvalue tests are presented in table (3). The null hypothesis of no co-integration is rejected using both trace and maximum eigenvalue tests as the t-statistics of both tests are higher than the critical values at the 5 percent level of significance. However, the null hypothesis of at most one co-integration equation could not be rejected at the 5 percent level of significance. Therefore, it can be concluded that there is one co-integration relationship between nominal GDP, money supply and inflation rate in Syria in the long-run.

Table 3:-Johansen Co-integration Test

\begin{tabular}{|c|c|c|c|c|}
\hline \multicolumn{5}{|c|}{ Unrestricted Cointegration Rank Test (Trace) } \\
\hline $\begin{array}{c}\text { Hypothesized No. of } \\
\text { CE(s) }\end{array}$ & Eigenvalue & Trace Statistic & Critical Value0.05 & Prob.\# \\
\hline None $* *$ & 0.494321 & 35.00633 & 29.79707 & 0.0115 \\
\hline At most 1 & 0.346478 & 13.86889 & 15.49471 & 0.0866 \\
\hline At most 2 & 0.021764 & 0.682145 & 3.841466 & 0.4088 \\
\hline \multicolumn{5}{|c|}{ Trace test indicates 1 cointegratingeqn(s) at the 0.05 level } \\
\hline \multicolumn{5}{|c|}{$* *$ denotes rejection of the hypothesis at the 0.05 level } \\
\hline \multicolumn{5}{|c|}{ \#MacKinnon-Haug-Michelis (1999) p-values } \\
\hline \multicolumn{5}{|c|}{ Unrestricted Cointegration Rank Test (Maximum Eigenvalue) } \\
\hline $\begin{array}{c}\text { Hypothesized No. of } \\
\text { CE }(s)\end{array}$ & Eigenvalue & $\begin{array}{l}\text { Max-Eigen } \\
\text { Statistic }\end{array}$ & Critical Value0.05 & Prob.\# \\
\hline None ** & 0.494321 & 21.13744 & 21.13162 & 0.0499 \\
\hline At most 1 & 0.346478 & 13.18674 & 14.26460 & 0.0735 \\
\hline At most 2 & 0.021764 & 0.682145 & 3.841466 & 0.4088 \\
\hline \multicolumn{5}{|c|}{ Max-eigenvalue test indicates 1 cointegratingeqn(s) at the 0.05 level } \\
\hline \multicolumn{5}{|c|}{$* *$ denotes rejection of the hypothesis at the 0.05 level } \\
\hline \multicolumn{4}{|c|}{ \#MacKinnon-Haug-Michelis (1999) p-values } & \\
\hline
\end{tabular}

Source: Compiled by authors based on EViews V.9

The long-run function of nominal GDP can be expressed as follows:

\section{LNGDP $=0.863890$ LNMS -0.028675 INF +4.404040 [20.2408] [-5.11485]}

Numbers between [ ] are t-statistics

It can be inferred from equation (10) that money supply has a positive and significant effect on the GDP in the longrun. The coefficient of 0.86 implies that a one percent increase in the money supply leads to about $0.86 \%$ increase in the nominal GDP. In contrast to the money supply, the inflation rate appears to have a negative effect on the GDP in the long-run, and the effect is significant at the $5 \%$ level of significance. The coefficient of -0.02867 implies that a one percent increase in the inflation rate leads to $2.867 \%$ decrease in the nominal GDP.

The long-run function of money supply can be expressed as follows:

$$
\begin{aligned}
& \text { LNMS = 0.033193 INF + 1.157555 LNGDP - 5.097919 } \\
& \text { [21.1941] [4.95344] }
\end{aligned}
$$

Numbers between [] are t-statistics

As shown in equation (11), both inflation rate and GDP have a positive and significant effect on money supply in the long-run. The coefficients imply that a one percent increase in the inflation rate leads to about $3.3 \%$ increase in the money supply, and a one percent increase in the GDP leads to $1.157 \%$ increase in the money supply. Hasanov et al. (2017) also concluded that money supply is positively related to both GDP and prices in Saudi Arabia. Moreover, Jiranyakul (2009) concluded that GDP has a positive impact on money supply in Thailand. However, our result came against the findings of Naeem et al. (2014) who reported no co-integration relationship between money supply and inflation in Syria in the long-run. This could be attributed to the differences in the time periods covered as the current study covers a longer time period than the previous one. 
The long-run function of inflation can be expressed as follows:

$$
\begin{aligned}
& \text { INF }=\mathbf{- 3 4 . 8 7 3 1 9} \text { LNGDP + 30.12659 LNMS + 153.5829 } \\
& \text { [-2.97258] [2.74930] }
\end{aligned}
$$

Numbers between [] are t-statistics

From equation (12), it can be noticed that GDP has a negative and significant effect on inflation rate in the long-run. The coefficient implies that a one percent increase in the GDP would be associated with $0.3487 \%$ decrease in the inflation rate. This means that an increase in the rate of economic growth is associated with more goods for money to chase, which puts downward pressure on the inflation rate (Denbel et al., 2016). Although the result is consistent with what is reported by (Bozkurt (2014) in Turkey, it is inconsistent with the findings reported by Al-Mosabbeh (2006) in Syria. This could be attributed to the longer time period of the current study comparing with Al-Mosabbeh (2006) study.

On the other hand, it can be noticed that money supply has a positive and significant effect on the inflation rate in the long-run. The coefficient implies that a one percent increase in the money supply leads to $0.3013 \%$ increase in the inflation rate. This finding is consistent with the monetarist view of the positive impact of money supply on price level. Al-Mosabbeh also recorded a positive effect of money supply on inflation in Syria. In addition, other studies have concluded this positive effect for example Jiranyakul (2009), Bozkurt (2014) and Bala and Chin (2018). However, our result came against the findings of Naeem et al. (2014) who reported no co-integration relationship between money supply and inflation in Syria in the long-run. The reason behind these different results could be attributed to the fact that the current study covers a longer time period than the previous one.

Table (4) summarizes the long-run relationship between nominal GDP, money supply and inflation rate in Syria.

\begin{tabular}{|c|c|c|}
\hline $\begin{array}{l}\text { The long-run relationship } \\
\text { between: }\end{array}$ & & \\
\hline GDP and money supply & $\begin{array}{l}\text { GDP has a positive effect on money } \\
\text { supply }\end{array}$ & $\begin{array}{l}\text { Money supply has a positive effect on } \\
\text { GDP }\end{array}$ \\
\hline GDP and inflation rate & $\begin{array}{l}\text { GDP has a negative effect on } \\
\text { inflation rate }\end{array}$ & $\begin{array}{l}\text { inflation rate has a negative effect on } \\
\text { GDP }\end{array}$ \\
\hline money supply and inflation rate & $\begin{array}{l}\text { Money supply has a positive effect } \\
\text { on inflation rate }\end{array}$ & $\begin{array}{l}\text { Inflation rate has a positive effect on } \\
\text { money supply }\end{array}$ \\
\hline
\end{tabular}

Table 4:-Long-run relationship between GDP, money supply and inflation rate

Source: Compiled by authors based on Johansen Co-integration Test

\section{Conclusion:-}

The aim of this study was to examine the long-run relationship between GDP, money supply and inflation rate in Syria over the period 1980 to 2012. The Johansen co-integration test was used in order to determine the existence of a long-run relationship between the three variables under study. The results revealed that there is one co-integration relationship between nominal GDP, money supply and inflation rate in Syria over the long-run. To be more specific, the GDP appears to be positively related to money supply but negatively related to inflation. Similarly, the inflation is positively related to money supply but negatively related to GDP. On the other hand, the money supply is positively related to both GDP and inflation over the long run.

Based on these results, it can be recommended that controlling the expansion of broad money supply (M2) is an important instrument in reducing the inflation rate in Syria over the long-run. Therefore, the Central Bank of Syria (CBS) needs to employ a tight monetary policy if the goal is inflation's reduction. Moreover, because of the negative effect of inflation on GDP, the monetary authorities should work on decreasing inflation in order to achieve a higher economic growth.

It is important to note though that with the limitation of data availability on Syria, the current study could not extend the data further than 2012, therefore future research that could cover a most up to date period would be very important to undertake. 


\section{References:-}

1. Ahmed, A. E. M., and Suliman, S. Z. (2011): The Long-Run Relationship between Money Supply, Real GDP, and Price Level: Empirical Evidence From Sudan. Journal of Business Studies Quarterly, 2(2), pp. 68-79.

2. Al-Fawwaz, T. M., and Al-Sawai'e, K. M. (2012): Output, Money, and Prices: The Case of Jordan. International Business Research, 5(12), pp. 223-229.

3. Al-Mosabbeh, I. (2006): Determinants of Inflation in Syria during the Period 1970-2004. MPRA Working Paper 46982. https://mpra.ub.uni-muenchen.de/46982/

4. Asteriou, D. and Hall, S. G. (2007). Applied Econometrics A Modern Approach. USA: Palgrave Macmillan.

5. Bala, U., and Chin, L. (2018): Asymmetric Impacts of Oil Price on Inflation: An Empirical Study of African OPEC Member Countries. Energies, (11), pp. 1-21.

6. Bello, M. Z., and Saulawa, M. A. (2013): Relationship between Inflation, Money Supply, Interest Rate and Income Growth (Rgdp) in Nigeria 1980-2010: An Empirical Investigation. Journal of Economics and Sustainable Development, 4(8), pp. 7-13.

7. Bozkurt, C. (2014): Money, Inflation and Growth Relationship: The Turkish Case. International Journal of Economics and Financial Issues, 4(2), pp. 309-322.

8. Brooks, C. (2014). Introductory Econometrics for Finance. (3ed ed.). USA: Cambridge University Press.

9. Denbel, F. S., Ayen, Y. W., and Regasa, T. A. (2016): The Relationship between Inflation, Money Supply and Economic Growth in Ethiopia: Co integration and Causality Analysis. International Journal of Scientific and Research Publications, 6(1), pp. 556-565.

10. Dickey D.A, and Fuller W.A. (1981): Distributions of the Estimators for Autoregressive Time Series with a Unit Root. Econometrica, (49), pp. 1057-1072.

11. Hasanov, F. J., Al-Rasasi, M. H., Al-Sayaary, S., and Al-Fawzan, Z. (2017): Demand for Broad Money in the Saudi Arabian Economy. Saudi Arabian Monetary Authority. Working Paper 6.

12. Jiranyakul, K. (2009): Relationship among Money, Prices and Aggregate Output in Thailand. The Empirical Economics Letters, 8(11), pp. 1063-1071.

13. Johansen, S., and Juselius, K. (1990): Maximum Likelihood Estimation and Inference on Cointegration —with Applications to the Demand for Money. Oxford Bulletin of Economics and statistics, 52(2), pp. 169-210.

14. Johansen, S. (1991): Estimation and Hypothesis Testing of Cointegration Vectors in Gaussian Vector Autoregressive Models. Econometrica: Journal of the Econometric Society, pp. 1551-1580.

15. Naeem, M., Mishaal, Y., and Abdulkarim, S. (2014): Analyzing The Relationship between Money Supply and Inflation in the Syrian Economy During (1996-2010). Tishreen University Journal for Research and Scientific Studies -Economic and Legal Sciences Series, 36(4), pp. 153-178.

16. Shams, N. A. (2012): Money, Income, and Prices in Bangladesh: A Cointegration and Causality Analysis. Journal of Economics and Sustainable Development, 3(7), pp. 82-88. 